\title{
University Governance To Intellectual Capital Formation In Nommensen University Medan Indonesia
}

\author{
Magdalena Judika Br Siringoringo ${ }^{1}$, Audrey M. Siahaan ${ }^{2}$, Iskandar Muda ${ }^{3}$, Syafruddin \\ Ginting ${ }^{4}$ \\ \{lenaringo@gmail.com ${ }^{1}$ \} \\ ${ }^{1,2}$ Student Postgraduate, Faculty Economic and Business, Universitas Sumatera Utara, Medan \\ Indonesia \\ ${ }^{3,4}$ Lecturer of Faculty Economic and Business, Universitas Sumatera Utara, Medan Indonesia
}

\begin{abstract}
Concerning observations and new findings, the following dynamic principals of good university governance are implemented by the University; transparency, accountability, fairness, and responsiveness. The research is done in Nommensen University Medan Indonesia, in which data is collected by depth interview, observation, and documentation. The intellectual capital in Nommensen University led to the internalization of vision, mission, and policies which have been implemented. Those policies cause Nommensen University to transform itself to become the center of academic excellent.
\end{abstract}

Keywords: University Governance, Intellectual Capital, Center of Academic Excellence.

\section{Introduction}

Good governance can be viewed in terms of whether the manager has functioned effectively and efficiently in an effort to achieve the stated goals (Zaman, 2015). The application of good governance needs to be supported by three interconnected pillars, namely the state and its tools as regulators, the business world (including universities) as market participants, and the community as stakeholders and users of business products / services (Gustafsson \& Lidskog, 2018).

The concept of good governance can and is appropriate to be applied in universities In connection with that, there arises a discourse on University Governance in the implementation of a higher education institution (Quyên, 2014). University governance can be seen as the application of the basic principles of the concept of "good governance" in the governance system and process in higher education institutions. Higher education institutions evolve in the creation of transformation and capitalization of knowledge itself so that ultimately higher education institutions become more comparable, flexible, transparent and competitive in terms of education, teaching and research. Higher education is affected by the number of new challenges, which has changed our way of teaching and research (Kosor, 2013).

Nevertheless, success in the formation and empowerment of intellectual capital cannot be achieved by itself without considering that there are elements of university governance that can support its sustainability. Specifically, intellectual capital as a forum for intellectual center of knowledge and human resources (Kianto, Ritala, Vanhala, \& Hussinki, 2018). It cannot be realized by itself without being supported by university governance (Todericiu \& Şerban, 2015). University governance is the foundation or pillar for the realization of intellectual capital in achieving competitive 
advantage. Meanwhile, the concept of human resource accounting defines human resources as valuable assets for the organization because it has the essence of the decision making process for both managerial and stakeholders (Guesalaga, Gabrielsson, Rogers, Ryals, \& Marcos Cuevas, 2018). Thus, the component of intellectual capital is a form of implementation of the principles of university governance namely transparency, accountability, fairness and responsiveness.

Based on the description above, this paper aims to describe and provide an understanding of the application of University governance to intellectual capital formation at Nommensen University Medan Indonesia.

\section{Literature Review}

Institutional theory provides an explanation of how the mechanism through which organizations try to harmonize their practices and characteristics with values and culture (Lapiņa, Kairiša, \& Aramina, 2015),(Bagautdinova, Gorelova, \& Polyakova, 2015)becomes institutionalized in a special organization. This means that, the transparency principle of university governance provides information needed by stakeholders related to intangible resources and university activities in the implementation of the higher education system. Intellectual capital disclosure not only provides credible information but can also provide reliable accounting information (Coste, Tudor, \& Pali-Pista, 2014) regarding intangible resources in the administration of higher education systems (Todericiu \& Şerban, 2015).

Good governance in universities is not singular in administrative prerogatives, but also in responsibility and joint efforts that involve the participation of all campus constituents as appropriate. Therefore, universities must continue to strive to realize good university governance as a system that is inherent in the dynamics of higher education. The application of the values of governance at the university can be internalized into the institution's own culture so that it becomes a system that strengthens competitive advantage.

The essence of intellectual capital in the effort to realize the university as a center of academic excellence is carried out through the Dharma of higher education. In line with its vision to be a center of academic excellence, science, technology and art are intellectual capital for universities in realizing their mission whose disclosure is expressed through the Tri Dharma of Higher Education (Ilyas \& Semiawan, 2012). First, teaching activities, namely by reviewing the indicators on: a) the content of the curriculum that is tailored to the needs of graduates. b) Learning materials that are up to date and full of enrichment. c) Adequate library and laboratory. d) The right and structured learning process. e) Process of proper and structure academic administration services. f) Professionalism of lecturers' education (Sadalia \& Lubis, 2015). g) Number of Professors / Professors at each study program in the faculty. h) Application of information technology (IT)-based information systems that support academics such as the Academic Information System (SISFO) (Ford \& Meyer, 2015).

The university as a forum for knowledge formation (De Moortel \& Crispeels, 2018) seeks to realize its vision and mission to be a center of academic excellence through improving the quality of human resources through teaching dharma. This discussion is also supported by a grounded theory that is institutional theory which explains that institutions play a role in the structure and social interaction through the process of 
realization and achievement as a center of formation and knowledge of knowledge, insight, creativity and culture.

Second, in supporting the implementation of the second dharma, namely research, universities are required to always act as sources of scientific information that is up to date, superior and useful (Saraite-Sariene, Gálvez Rodríguez, \& Haro de Rosario, 2018). For this reason various infrastructures have been prepared, including internet services for all students, hot spots in several regions and facilities to access various international journals. The results of this discussion are in accordance with the institutional theory which states that education is developing very rapidly along with technological advances and cultural heterogeneity (Carvalho, Cunha, Lima, \& Carstens, 2017) and therefore, universities have evolved to become an institution that can answer the needs and dynamics of knowledge growth and development. Institutional can also be influenced or even affect its environment if the structure, interaction and changes in the environmental system are also increasingly complex. In order to answer the dynamics of the complexity of the growth and development of knowledge, the university carries out various research activities and to improve the quality of research that has innovation and applicability various supporting infrastructures have been provided.

Third, community service activities are carried out as the implementation of knowledge carried out by institutionalizing through scientific methods directly to the public. The purpose of this service program is to explore, manage and utilize research results to be implemented to the community. The University as a forum that reflects the progress of knowledge, thinking, technology and various aspects of life contributes to the structure and social interaction (Carvalho et al., 2017) through the process of realizing and achieving it as the center of intellectual capital formation and development.

The university as part of an autonomous higher education institution always strives to maintain and enhance trust in stakeholders, both internally and externally in terms of the quality of the products of university. In maintaining the reputation and trust mandated by stakeholders, the university has a Quality Assurance Institution. The systematic, consistent and continuous quality assurance implementation is absolutely necessary so that: (a) the vision, mission and goals of the university can be achieved (Marzuki, Subramaniam, Cooper, \& Dellaportas, 2017), (b) the interests and demands of the relevant parties or stakeholders can be met, (c) comply with and fulfill provisions of relevant regulations and laws. Institutional theory underlies a concept that every individual in a particular institution or organization acts and behaves in accordance with the normative standards of the institution.

\section{Discussion}

This paper is the result with a single instrumental case study which seeks to explore more in one case about the dynamics of university governance in the formation of intellectual capital at the university. Data was collected through interviews and observations conducted between June 2018 and September 2018 involving a number of informants including officials, senate members, employees both at the administrative and academic levels and at the quality assurance body, as well as lecturers, students and alumni including a number of informants who in the previous period had served both as university functionaries and deans. 
The results of interviews, observations, and documentation studies were changed into written forms according to their respective formats. The data display stage contains semi-finished data processing that is uniform in written form that has a clear theme flow into a categorization matrix according to the themes that have been grouped and categorized. Furthermore, the data on these themes are broken down into more concrete and simple form or sub-themes using coding and grouping which ends with giving the codes of the sub-themes according to the previous verbatim interviews. The concluding / verification stage is the last stage. The conclusions lead to answers to the proposed research questions and reveal "what" and "how" research findings. The final narrative is expected to be a contribution to the theory that has been excavated so far.

\section{Result And Discussion}

The following are the findings of the application of university governance at the university:

\subsection{Transparency}

The University is responsible for the obligation to disclose information and provide information to stakeholders so that the position and management of corporations (universities) can reflect the real conditions and expectations of universities in the future. Institutional theory provides an explanation of how the mechanism through which organizations seek to harmonize their practices and characteristics with social and cultural values becomes institutionalized in specific organizations.

\subsection{Accountability}

The University as a public policy and service actor is responsible to the public for its attitude, behavior and behavior in carrying out the duties, functions and authorities given to it because the university cannot be separated from the public as its stakeholders. Accountability about attitudes (Kelly, 2017), behavior and policies in the framework of carrying out their duties, functions and responsibilities to the public is what is called accountability. University management which is held through the principle of accountability from good university governance can improve sustainability and legitimacy as public service bodies / stakeholders and stakeholders (Speziale, 2012).

\subsection{Equality and Fairness}

To fulfill the principle of equality and fairness at the university level, relations with staff and teaching staff are also maintained, namely by treating employees as valuable resources through means of knowledge-based management systems in accordance with the concept of human resource accounting which states that humans are valuable resources for organization. An effective performance appraisal system contains two basic systems that are interconnected, namely evaluation and feedback. Performance appraisal motivates employees to continue to work better if employees feel that the performance appraisal process is conducted fairly and fairly. 


\subsection{Concern (Responsiveness)}

The university as a public service provider has the task and function of providing support and assistance or service to its community by implementing university governance through the principle of concern (responsiveness). The form of care (responsiveness) is to become a reactive, sympathetic, sensitive institution in responding to requests from its stakeholders. The University responds to the dynamics of university governance through the principle of concern (responsiveness) which makes universities as institutions that can answer the needs and growth and development of knowledge.

In the process of Intellectual capital, the university always tries to adopt the principles of university governance embodied in the formulation and implementation of the Strategic Plan, self-evaluation activities, assessment of work programs based on activities in an effort to gain legitimacy from its stakeholders. The purpose of intellectual capital disclosure in higher education institutions consists of 3 fundamental parts which explain the internalization of institutional strategies through indicators that lead to: (1) vision of the institution; (2) intangible resources and activities; and (3) system of indicators (Ramírez Córcoles \& Tejada Ponce, 2013).

The University embodies the principle of transparency to its stakeholders through intellectual capital disclosure. Intellectual capital disclosure is an effort to improve the transparency and accountability of universities in terms of management. Intellectual capital disclosure provides accounting information that is not only reliable, but also very relevant in decision making for stakeholders who use accounting information. Information in a transparent and accountable manner ensures the assessment of stakeholders for the existence and image developed by the university because in a process of providing services that are open and can be easily known by stakeholders in need.

\section{Conclusion}

This research is based on institutional theory that has been grounded about higher education as an institution. Observations and findings about university governance were carried out in an effort to realize intellectual capital formation at Nommensen University in Medan. The results of the study explain the dynamics of good university governance through the principles of good governance practices, namely transparency, accountability, equality and fairness, and caring is carried out as the process of forming intellectual capital. Furthermore, the essence of intellectual capital in the realization of the center of academic excellence is carried out through the Tri Dharma of Higher Education.

This study also has implications in the field of accounting especially regarding human resource accounting in relation to the good governance dynamics in the process of intellectual capital formation. The results of the study explain university governance through the principles of good governance practices, namely transparency, accountability, equality and fairness, and caring for intellectual capital formation. Because this study only explains the phenomena of one object of research, the results of research on university governance in the process of intellectual capital formation cannot be generalized. For further research, it can explore more deeply by conducting comparisons between several institutions incorporated in one organization, namely universities. 


\section{References}

[1] Bagautdinova, N. G., Gorelova, Y. N., \& Polyakova, O. V. (2015). University Management: From Successful Corporate Culture to Effective University Branding. Procedia Economics and Finance, 26(15), 764-768. https://doi.org/10.1016/S2212-5671(15)00836-9

[2] Carvalho, A. D. P., Cunha, S. K. da, Lima, L. F., \& Carstens, D. D. (2017). The role and contributions of sociological institutional theory to the socio-technical approach to innovation theory. RAI Revista de Administração e Inovação, 14(3), 250-259. https://doi.org/10.1016/j.rai.2017.02.001

[3] Coste, A. I., Tudor, A. T., \& Pali-Pista, S. F. (2014). Compliance of Non-current Assets with IFRS Requirements Concerning the Information Disclosure - Case Study. Procedia Economics and Finance, 15(14), 1391-1395. https://doi.org/10.1016/S2212-5671(14)00603-0

[4] De Moortel, K., \& Crispeels, T. (2018). International university-university technology transfer: Strategic management framework. Technological Forecasting and Social Change, 135(February 2017), 145-155. https://doi.org/10.1016/j.techfore.2018.05.002

[5] Ford, R., \& Meyer, R. (2015). Competency-based Education 101. Procedia Manufacturing, 3(Ahfe), 1473-1480. https://doi.org/10.1016/j.promfg.2015.07.325

[6] Guesalaga, R., Gabrielsson, M., Rogers, B., Ryals, L., \& Marcos Cuevas, J. (2018). Which resources and capabilities underpin strategic key account management? Industrial Marketing Management, (May 2015), 1-13. https://doi.org/10.1016/j.indmarman.2018.05.006

[7] Gustafsson, K. M., \& Lidskog, R. (2018). Boundary organizations and environmental governance: Performance, institutional design, and conceptual development. Climate Risk Management, 19(October 2017), 1-11. https://doi.org/10.1016/j.crm.2017.11.001

[8] Ilyas, I. P., \& Semiawan, T. (2012). Production-based Education (PBE): The Future Perspective of Education on Manufacturing Excellent. Procedia - Social and Behavioral Sciences, 52, 5-14. https://doi.org/10.1016/j.sbspro.2012.09.436

[9] Kelly, P. T. (2017). Integrating Leadership Topics into an Accounting Ethics Course - Preparing Students for a Challenging Profession (pp. 141-180). https://doi.org/10.1108/S1085-462220170000020007

[10] Kianto, A., Ritala, P., Vanhala, M., \& Hussinki, H. (2018). Reflections on the criteria for the sound measurement of intellectual capital: A knowledge-based perspective. Critical Perspectives on Accounting. https://doi.org/10.1016/j.cpa.2018.05.002

[11] Kosor, M. M. (2013). Efficiency Measurement in Higher Education: Concepts, Methods and Perspective. Procedia - Social and Behavioral Sciences, 106, 1031-1038. https://doi.org/10.1016/j.sbspro.2013.12.117

[12] Lapina, I., Kairiša, I., \& Aramina, D. (2015). Role of Organizational Culture in the Quality Management of University. Procedia - Social and Behavioral Sciences, 213, 770-774. https://doi.org/10.1016/j.sbspro.2015.11.472

[13] Marzuki, M., Subramaniam, N., Cooper, B. J., \& Dellaportas, S. (2017). Accounting academics' teaching self-efficacy and ethics integration in accounting courses. Asian Review of Accounting, 25(1), 148-170. https://doi.org/10.1108/ARA-09-2015-0088 
[14] Quyên, Đ. T. N. (2014). Developing University Governance Indicators and their Weighting System Using a Modified Delphi Method. Procedia - Social and Behavioral Sciences, 141, 828-833. https://doi.org/10.1016/j.sbspro.2014.05.144

[15] Ramírez Córcoles, Y., \& Tejada Ponce, Á. (2013). Cost-benefit analysis of intellectual capital disclosure: University stakeholders' view. Revista de Contabilidad, 16(2), 106-117. https://doi.org/10.1016/j.rcsar.2013.07.001

[16] Sadalia, I., \& Lubis, A. N. (2015). Discriminant Analysis of Intellectual Capital Model of State University in Medan. Procedia - Social and Behavioral Sciences, 211(September), 476-480. https://doi.org/10.1016/j.sbspro.2015.11.063

[17] Saraite-Sariene, L., Gálvez Rodríguez, M. del M., \& Haro de Rosario, A. (2018). Exploring determining factors of web transparency in the world's top universities. Revista de Contabilidad, 21(1), 63-72. https://doi.org/10.1016/j.rcsar.2017.07.004

[18] Speziale, M.-T. (2012). Differentiating Higher Education Accountability in the Global Setting: A Comparison Between Boston University and University of Bologna. Procedia - Social and Behavioral Sciences, 47, 1153-1163. https://doi.org/10.1016/j.sbspro.2012.06.794

[19] Todericiu, R., \& SSerban, A. (2015). Intellectual Capital and its Relationship with Universities. Procedia Economics and Finance, 27(15), 713-717. https://doi.org/10.1016/S2212-5671(15)01052-7

[20] Zaman, K. (2015). Quality guidelines for good governance in higher education across the globe. Pacific Science Review B: Humanities and Social Sciences, 1(1), $\quad 1-7 . \quad$ https://doi.org/10.1016/j.psrb.2016.01.001. 